\title{
The effects of large wood elements during an extreme flood in a small tropical basin of Costa Rica
}

\author{
L. $\mathrm{Mao}^{1} \& \mathrm{~F} . \mathrm{Comiti}^{2}$ \\ ${ }^{1}$ Department of Geography, University of Hull, UK \\ ${ }^{2}$ Faculty of Science and Technology, \\ Free University of Bozen-Bolzano, Italy
}

\begin{abstract}
In-channel large wood elements (LW) enter the river system as a consequence of natural processes independent of channel activity (i.e. windthrow, large landslides, extended wildfire, disease outbreaks), or as a result of river processes (bank erosion, avulsions). LW exert a substantial beneficial influence on river morphology and freshwater biodiversity, but on the other hand may increase flood hazards in densely inhabited floodplains. This is due to a variety of processes, such as flow surges following collapse of temporary wood dams, strengthening of debris flows, local bed scour and local bank erosion, and clogging of culverts and bridges. However, despite a general consensus among populations and river managers about the hazards related to floating wood during floods, few studies have addressed the real contribution of LW to flood damages, as well as its sources and effects on flood dynamics. This paper presents a post-event analysis in the Río Portalón, a small tropical basin in the Pacific coast of Costa Rica, which experienced an extreme flood in September 2005. On that occasion, floating wood apparently had a considerable role in flood dynamics and in causing damages to the nearby village. Interviews with local people and a simple field survey were used to shed light on event dynamics, and in particular on role played by LW. Finally, a range of options for the management of riparian vegetation in tropical areas are discussed.
\end{abstract}

Keywords: riparian vegetation, large wood elements, tropical basin, flood risk, river management. 


\section{Introduction}

Large wood elements (LW, i.e. woody elements $>10 \mathrm{~cm}$ in diameter and $>1 \mathrm{~m}$ in length) have a substantial beneficial influence on river morphology $[16,25]$, hydraulics and sediment transport [11, 28] and freshwater biodiversity [2, 7]. LW can enter the river system as a consequence of processes independent of channel activity (i.e. windthrow, large landslides, extended wildfire, disease outbreaks), or as a result of river processes (bank erosion, avulsions). LW sources are thus subject to a very relevant spatio-temporal variability due to the activation of the associated processes, so that wood input rates can vary considerably for streams in the same region and even for different reaches of the same river [23]. The amount of in-channel large wood is therefore strongly connected to both the availability of trees in the riparian and basin area, and to the magnitude and frequency of input and output processes. Beside the positive effects on stream ecosystems, in-channel wood may also increase flood hazards. This can be caused by a variety of processes, such as flow surges following the collapse of temporary wood dams, inclusion and strengthening of debris flows, local bed scour and local bank erosion, and clogging of culverts and bridges [13]. Nonetheless, these potential hazards are strongly dependent on the degree of human presence within the catchment (frequency and type of road crossings, proximity and density of human infrastructures adjacent to the channels).

Despite a general consensus among populations and river managers about the hazards related to floating wood during floods, few studies have addressed the real contribution of LW to flood damages, or its sources and effects on flood dynamics. Comiti et al. [8], analysing a flash flood event in a mountain basin of the Slovenian Alps, concluded that the transfer of wood elements from the headwaters to the main channel was mostly associated with debris flows, and other LW sources were represented by forested floodplains in aggrading reaches. Entrained LW were then trapped by bridges, which were under-designed even for water and sediment fluxes alone. Therefore, in contrast to the generalized feeling that LW were indeed the main "culprit" for those damages, Comiti et al. [8] argued that LW possibly increased the final damages by exacerbating an already critical situation.

This paper presents a simplified post-event analysis in the Río Portalón, a small tropical basin in the Pacific coast of Costa Rica, which experienced an extreme flood in September 2005. On that occasion, floating wood apparently had a considerable role in flood dynamics and in causing damages to the nearby village. Interviews with local people and a basic field survey were used to shed light on the event dynamics, and in particular on role played by LW. Finally, a range of options for the management of riparian vegetation in tropical areas will be discussed.

\section{Study site and description of the flood event}

The Río Portalón is a small $\left(17 \mathrm{~km}^{2}\right.$ ) mountain basin (maximum elevation of 760 $\mathrm{m}$ a.s.l) on the west coast range of Costa Rica, $40 \mathrm{~km}$ south of Quepos (Fig. 1). 


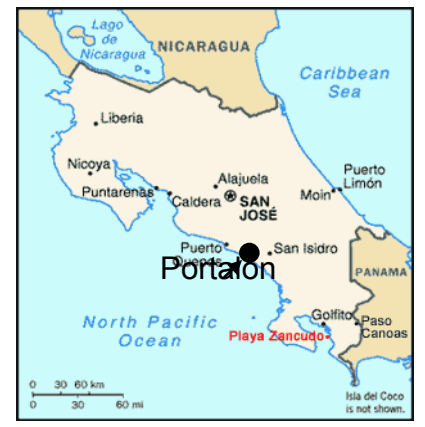

Figure 1: $\quad$ Location of the Río Portalón basin.

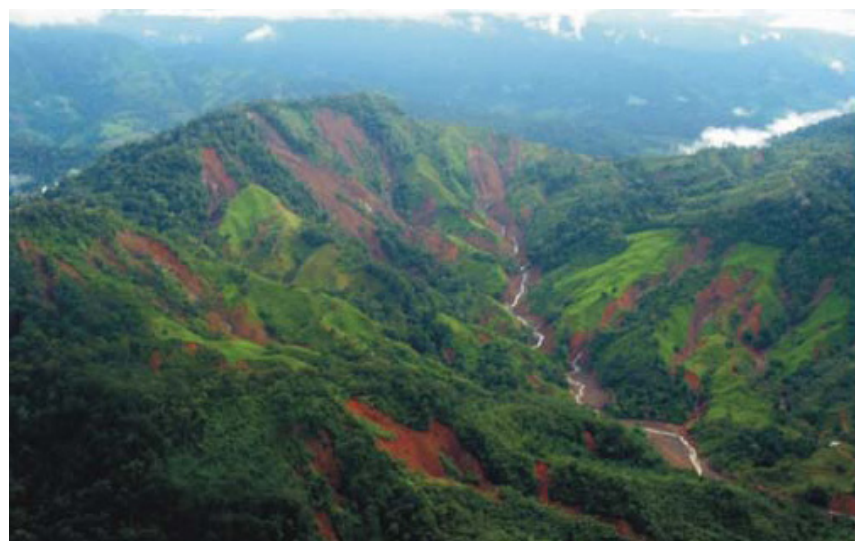

Figure 2: Multiple landslides triggered by the September 2005 event in the Río Guabas. The general condition of the Río Portalón has been reported to be similar (photo taken from [3]).

The river exits its confined segment at the hamlet of Portalón and then flows for $4 \mathrm{~km}$ towards the ocean on the narrow coastal plain.

The basin features steep hillslopes, with widespread landslides and debris flows. Soils are generally very thick, ranging from 3 to $10 \mathrm{~m}$ in depth, and the underneath bedrock is mainly a turbiditic sedimentary rock of the Tertiary age [24]. In September 2005, the passage of the hurricane Rita generated diffuse flooding and mass wasting on the whole Central pacific area of Costa Rica, creating major economic and social impacts on the area [24]. In the Río Portalón basin, several landslides were triggered as a consequence of the intense precipitations (Fig. 2). The landslides supplied the main channel and the tributaries with large quantities of sediment and large mature trees.

Interviews to Portalón residents - carried out on February 2008 - indicate that, on September 23 2005, very intense rainfall started at 10 AM and continued until the late evening, eventually leading to a high flood peak. The event transported relevant quantities of sediments and driftwood, impacting heavily the Portalón 
village. Most of the people interviewed refer to the formation of a "wood plug" in the confined reach, which caused the flood surge once it collapsed. Witnesses also reported that most of the wood was transported during the peak of the flood. Furthermore, local people claimed a similar event in the Río Portalón occurred about 50 yr ago. Forty-three houses were completely destroyed and 300 people had to be rescued and relocated from the Portalón and other villages of the area. Furthermore, there were extensive damages to electric and water supply systems as well as the collapse of an important bridge on a national road, which prevented emergency vehicles from reaching the area for few days. A preliminary survey of the Comisión Nacional de Prevención de Riesgos $y$ Atención de Emergencias (CNE) reported that the main channel along its lower reach (near the village), aggraded by 2 to $4 \mathrm{~m} \mathrm{[24].}$

\section{Field-based estimation of the flood peak discharge}

A field survey along the Río Portalón main channel was carried out on February 2008 , in order to test the hypothesis that a dam-break surge was released by the collapse of a LW jam (the "wood plug" reported by the inhabitants). After an inspection of the entire channel, 7 reaches were identified (Fig. 3). Seven crosssections were measured along with the longitudinal bed slope. High-water marks (i.e. deposited driftwood, scars on trees, gravel deposits) were used to estimate the peak stage for each cross-section (Fig. 4). Bed slope ranges between 0.015 and 0.05 , whereas bankfull width varies between $16 \mathrm{~m}$ and $23 \mathrm{~m}$.

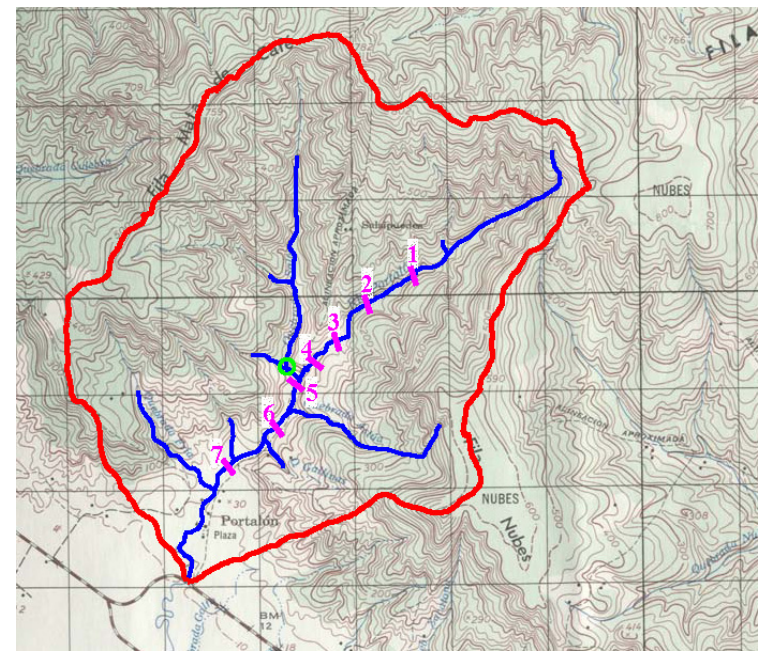

Figure 3: The Río Portalón basin and the location of the seven cross-sections where the peak flood has been estimated. 

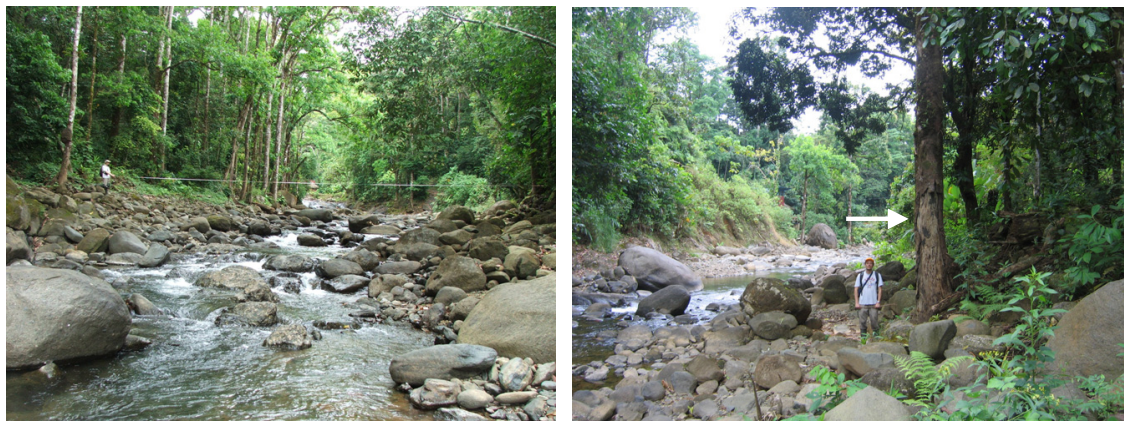

Figure 4: $\quad$ Field survey of cross-sections (left) and an example of flood mark (tree scar, right) Note the presence of very large boulders $(D>1.5$ m) within the channel.

Simple methods have been used in order to estimate the maximum flood discharge based on the field evidences, due to the lack of any gauging station in the basin. The first method relies on the assumption that critical flow conditions $(F r \approx 1)$ were established along the reach during the flood, being critical conditions a limiting state in high-gradient streams featuring cascade and step pool morphologies $[9,10,15,20]$. The critical velocity $\left(V_{c}\right.$, in $\left.\mathrm{m} \mathrm{s}^{-1}\right)$ is calculated from the estimated mean depth (assumed to be critical, $h_{c}$, in $\mathrm{m}$ ) and the acceleration due to gravity $\left(g=9.81 \mathrm{~m} \mathrm{~s}^{-2}\right)$ as:

$$
V_{c}=\sqrt{g h_{c}}
$$

The second method used in this study is Jarrett's [17] formula for the calculation of Manning's roughness coefficient. Jarrett developed an equation which relates channel roughness to bed slope $(S)$ and hydraulic radius $(R$, in $\mathrm{m})$. Reformulated in terms of mean velocity $(V)$, the equation reads as follows:

$$
V=3.17 R^{0.83} S^{0.12}
$$

The third method is based on flow competence, i.e. the maximum clast size of the transported sediments. This was assumed to be the largest boulders still lying on the bed surface and that had been transported by the event. The intermediate axis diameters of the 10 largest boulders found around the cross-section were measured. The critical velocity required to move the averaged maximum clast diameter $(D$, in $\mathrm{m})$ was calculated by the empirical formula of Costa [12]:

$$
V=5.2 D^{0.49}
$$

For all the methods, once the velocity is estimated, the peak discharge $(Q$, in $\mathrm{m}^{3} \mathrm{~s}^{-1}$ ) is obtained multiplying velocity by the cross-sectional wetted area (in $\left.\mathrm{m}^{2}\right)$. 


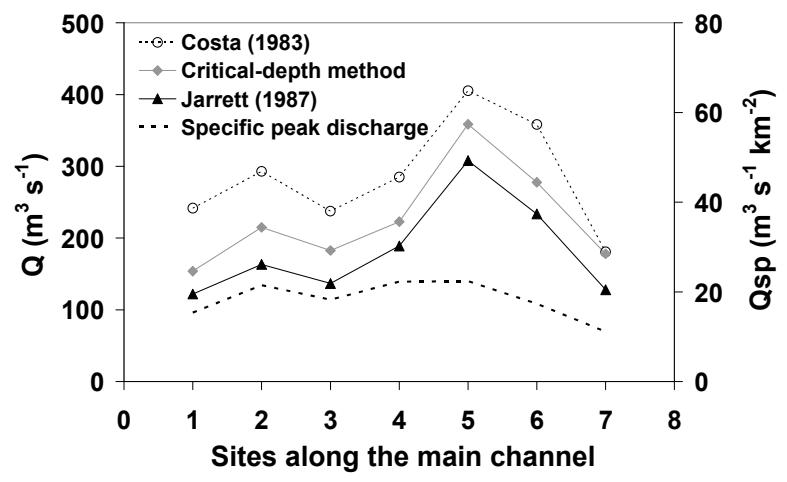

Figure 5: $\quad$ Estimated peak flood discharges $(Q)$ along the Río Portalón main channel, from upstream (1) to downstream (7) cross-sections. The specific peak discharge $\left(Q_{s p}\right)$ trend based on the critical-depth discharge calculated values is also showed.

The three mentioned methods used to estimate the peak discharge led to rather different results in absolute terms (Fig. 5). The method based on flow competence represents an upper estimate for peak discharges, whereas the Jarrett's formula provides values of $Q$ which are, on average, lower by $8 \%$ than the critical-depth method which is considered to be the most reliable one. However, it is worth noting that the relative longitudinal trend showed by all methods is consistent.

\section{Wood dynamics and effects during the flood event}

Looking at Fig. 5, peak discharge appears to steadily increase downstream due to the larger catchment area down to section 4. Peak discharge then nearly doubles (from 220 to $360 \mathrm{~m}^{3} \mathrm{~s}^{-1}$ ) passing from section 4 to 5, i.e. just after the confluence with a right tributary, the Quebrada Salto, to abruptly decrease at downstream sections 6-7.

A field inspection revealed that the basin drained by the Quebrada Salto was heavily affected by landslides which supplied large amount of sediments and large tress to that tributary. The narrow width of the Quebrada Salto has likely led to the formation of temporary jams of logs and boulders, with a considerable capacity to store water and sediments behind them. Despite the lush vegetation which rapidly grew at the channel margins after the flood, some evidences of the presence of large log jams were observed in at least 2 sites along the Quebrada Salto. In particular, the presence of several wood pieces just in front of the confluence with small debris flow channel, along with immobile boulders and sediment accumulation upstream reveals the likely position of one of this log jam (Fig. 6), a few hundred meters upstream of the junction with the Río Portalón (circle on Fig. 3). However, it is worth noting the large specific peak discharge $\left(\sim 20 \mathrm{~m}^{3} \mathrm{~s}^{-1} \mathrm{~km}^{-2}\right)$ characterizing the event already upstream of the Quebrada 
Salto, thus suggesting that the extreme flood magnitude is most likely attributable to the very intense precipitations.

The collapse of such jam (about 4m-high) during the flood event may have caused a small surge wave transporting sediment and wood into the main channel, and the impulsive nature of the flood at its peak was indicated by local people during the interviews. However, the sharp increase in peak discharge at section 5 is nevertheless consistent with the augmented drainage area (Fig. 3). On the other hand, the sudden drop in the estimated peak discharges at section 6 hints to a rapid attenuation of the flood wave typical of small dam-breaks in mountain rivers (Fig. 5). As to the even lower discharge value at section 7 , it can be attributed to the attenuation due to some overbank flows occurred on the left side of the channel between cross-section 6 and 7 .

A quick survey of wood pieces along the analyzed segment of the Río Portalón revealed a low amount of LW volume, i.e. $7 \mathrm{~m}^{3}$ per ha of channel area.

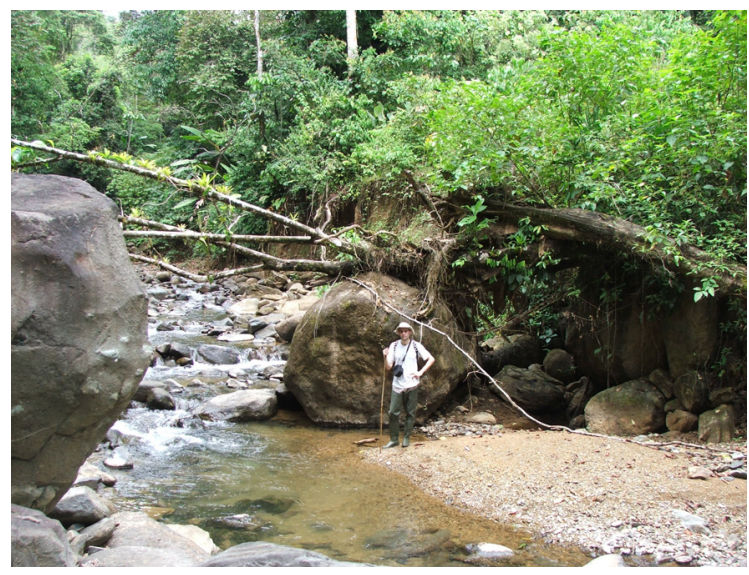

Figure 6: Boulders and wood pieces in one of the likely locations of the log jams.
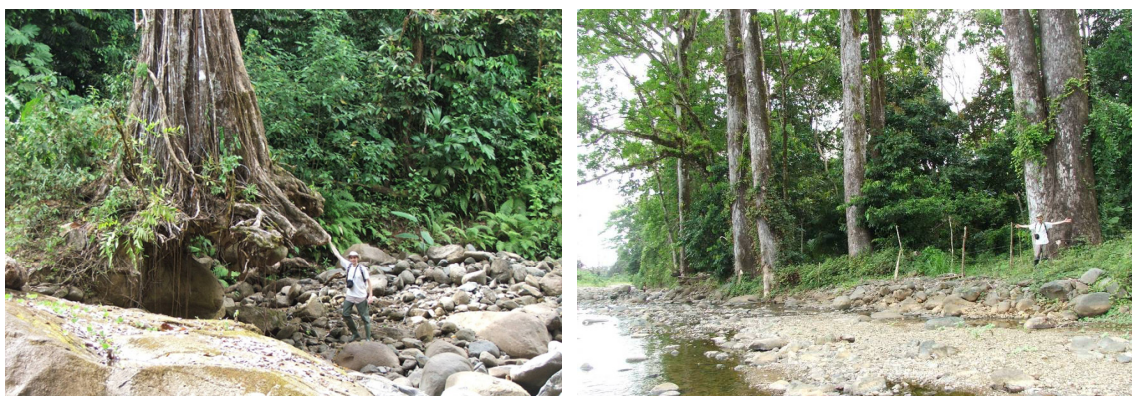

Figure 7: Large trees growing at the margins of the Río Portalón main channel. 
Wood elements were relatively large, with an average length and diameter of 6.2 $\mathrm{m}$ and $0.37 \mathrm{~m}$, respectively. However very large trees are ready to be recruited at channel margins (Fig. 6).

Even though very little is known about volumes and dynamics of wood in tropical rivers, the measured wood quantities are comparable to what Gomi et al. [14] found on headwater channels of the Peninsular Malaysia. The limited amount of in-channel wood pieces is due to their relatively short residence time in such environments, because of the frequent flashy floods events with large transport capacity as well as for the high decay rates [6, 14]. However, recent investigation in several other streams of Costa Rica featuring lower bed slopes [6] showed that wood loading can be rather large even in tropical basins. The very limited quantity of wood lying within the Portalón channel contrasts with the huge amount of driftwood transported by the September 2005 flood and deposited on the floodplain at the Portalón village (Fig. 8). Field observations and reports by witnesses suggest that most of the large trees which destroyed the buildings and the bridge were recruited from the forested banks just upstream of the town, where bed aggradation led to channel avulsion. This is in agreement with the fact that long wood elements are unlikely to travel long distance in narrow channels $[5,19]$.
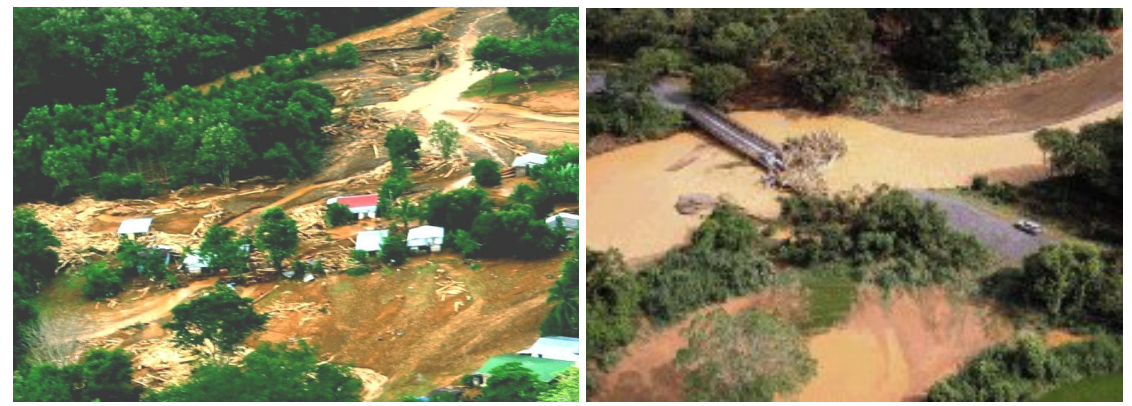

Figure 8: Wood elements lying on the flooded portion of the Portalón village (left) and accumulated on the collapsed bridge (right). The photos have been taken from the on-line version of the newspaper Al Dia $\left(26^{\text {th }}\right.$ September 2005).

\section{Management options for large wood and riparian vegetation}

Forest effectiveness in protecting hillslopes from soil erosion, landslides and debris flows for "ordinary" events is widely recognised [1, 27]. However, the forest cover may not prevent high magnitude geomorphic events from occurring, and sometimes mature plants removed and transported to the river network can increase the catastrophic effect and the hazard impacts of flood events due to wood jam collapses, reduced conveyance of critical cross-sections, and increased loading conditions on bridge piers. Such an adverse effect usually drives the 
decision of river managers to "clean-up" the river network from in-channel wood and to periodically cut riparian vegetation on floodplain. This practice is detrimental to stream ecology but on the other hand has also dubious effectiveness to reduce the hazards of high magnitude flood events. As showed by the Río Portalón case, wood stored in channels is only a little portion of the wood transported during extreme events, and the movement of in-channel logs is much reduced during low to moderate floods. Thus, for most period of time the in-channel wood lies relatively stable in the river system contributing to stabilize the bed, to limit the sediment transport and to create discontinuities that provide habitats for fishes and macroinvertebrates communities. Considerable amount of wood, which can create unstable jams, is recruited from slopes instabilities spread on the basin and eroded banks only during high magnitude floods. These infrequent floods are able to transport substantial loads of sediments and modify substantially the river bed due to erosion/deposition processes, which can represent the main threat even without any floating wood.

In the densely populated European and Japanese Alps, excessive wood transport is controlled by in-channel control works for wood retention. The choice of the most appropriate retention structure depends on channel width and on the amount of large wood potentially transportable by flood events [21]. Filter concrete check dams, rope net barriers and cable filter dams are the most effective structures [21]. To reduce the vulnerability of single in-channel infrastructure such as bridges, solutions as debris sweepers - vertically affixed to the upstream side of piers - might be an option, but their effectiveness under extreme flood conditions is yet to be demonstrated [4].

A more effective management option against flood risk - not only due to floating wood - would be to avoid any reconstruction or building of valuable structure in flood-prone areas. The adoption of a careful land use planning should of course be negotiated with local communities in order to achieve a prevalent social acceptance. As a compatible strategy for flood hazard reduction, wood recruitment and transport processes have been recently modelled [18] and considered in hazard mapping [22, 26]. However, these mapping methods usually require the availability of well calibrated probabilistic regional curves for flood-design estimation and detailed maps of landslide prone areas land use and forest vegetation typologies [22], and have been implemented experimentally only in Alpine areas.

\section{Conclusions}

In the Río Portalón, field surveys and interviews to local people indicate that large quantities of trees were supplied to the channel network during the 2005 flood event, likely creating some temporary wood dams. However, the flow surge associated to their collapse is very unlikely to have determined the flood itself, whose catastrophic consequences can be traced to the severity of the precipitation event. The reduced amount of wood lying on the channel contrasts with the huge quantity of trees transported during the flood. This suggests that the cleaning of wood from the river network is not an effective strategy in 
reducing flood hazards since wood jams in the upper part of the basin are created by trees delivered by landslides, and wood transported to the village are likely to be supplied by floodplains in the lower section of the stream. In-channel control works such as rope net barriers and cable filter dams are effective in capturing driftwood but are usually expensive and require high maintenance. It is thus preliminarily suggested that, in a situation like the study case, a more effective strategy option against flood risk would be to avoid any reconstruction within the floodplain, where the Portalón village was and still is located.

\section{Acknowledgements}

This research was funded by the EU Project INCO-CT-2004-510735 EPIC FORCE (Evidence-based policy for integrated control of forested river catchments in extreme rainfall and snowmelt). L. Mao is currently supported at the University of Hull by a Marie-Curie fellowship (EU $7^{\text {th }}$ Framework Programme; PIEF-GA-2008-219294).

\section{References}

[1] Andreassian, V., Waters and forests: from historical controversy to scientific debate. Journal of Hydrology, 291, pp. 1-27, 2004.

[2] Benke, A.C., Wallace, J.B., Influence of wood on invertebrate communities in streams and rivers. American Fisheries Society Symposium, 37, pp. 149177, 2003.

[3] Bonilla, E., Chaves, I., Esquivel, L., Madrigal, J., Mendez, J. \& Sjobohm, L., Casos frecuentes de Amenaza y Vulneraqbilidad. Medidas de prevencion y mitigacion, Comisión Nacional de Prevención de Riesgos y Atención de Emergencias, Costa Rica, 2006.

[4] Bradley, J.B., Richard, D.L., Bahner, C.D., Debris control structure, evaluation and countermeasures. Hydraulic Engineering Circular, 9, U.S. D.T., pp. 179, 2005.

[5] Braudrick, C.A., Grant, G.E., Transport and deposition of large woody debris in streams: a flume experiment. Geomorphology, 41, pp. 263-283, 2001.

[6] Cadol, D., Wohl, E.E., Goode, J.R., Jaeger, K.L., Wood distribution in neotropical forested headwater streams of La Selva, Costa Rica. Earth Surface Processes and Landforms, 34, pp. 1198-1215, 2009.

[7] Collier, K.J., Halliday J.N., Macroinvertebrate-wood associations during decay of plantation pine in New Zealand pumice-bed streams: Stable habitat or trophic subsidy? Journal of the North American Benthological Society, 19, 1, pp. 94-111, 2000.

[8] Comiti F., Mao L., Preciso E., Picco L., Marchi L., Borga M., Large wood and flash floods: evidence from the 2007 event in the Davča basin (Slovenia). In Monitoring, Simulation, Prevention and Remediation of Dense and Debris Flows II, eds. De Wrachien D., Brebbia C.A., Lenzi M.A., WIT Press, 60, pp. 173-182, 2008. 
[9] Comiti F., Mao L., Wilcox A., Wohl E.E., Lenzi M.A., Field-derived relationships for flow velocity and resistance in high-gradient streams. Journal of Hydrology, 340(1-2), pp. 48-62, 2007.

[10] Comiti, F. Cadol, D., Wohl, E., Flow regimes, bed morphology, and flow resistance in self-formed step-pool channels. Water Resources Research, 45, W04424, doi:10.1029/2008WR007259, 2009.

[11] Comiti, F., Andreoli, A., Mao L., Lenzi M.A., Wood storage in three mountain streams of the Southern Andes and its hydro-morphological effects. Earth Surface Processes and Landforms, 33, pp. 244-262, 2008.

[12] Costa, J.E., Paleohydraulic reconstruction of flash-flood peaks from boulder deposit in the Colorado front range. Geological society of American bulletin, 94, pp. 986-1004, 1983.

[13] Diehl, T.H., Potential drift accumulation at bridges. U.S. Department of Transportation, Federal Highway transportation, FHWA-RD-97-028, 1997.

[14] Gomi, T., Sidle R.C., Noguchi, S., Negishi, J.N., Nik, A.R., Sasaki, S., Sediment and wood accumulations in humid tropical headwater streams: Effects of logging and riparian buffers. Forest Ecology and Management, 224, pp. 166-175, 2006.

[15] Grant, G.E., Critical flow constrains flow hydraulics in mobile-bed streams: A new hypothesis. Water Resources Research, 33(2), pp. 349-358, 1997.

[16] Gurnell, A.M., Piegay, H., Swanson, F.J., Gregory S.V., Large wood and fluvial processes. Freshwater Biology, 47, pp. 601-619, 2002.

[17] Jarrett, R.D., Errors in slope-area computations of peak discharges in mountain streams. Journal of Hydrology, 96, pp. 53-67, 1987.

[18] Lancaster, S.T., Hayes S.K., Grant, G.E., Modelling sediment and wood storage and dynamics in small mountainous watersheds. Geomorphic Processes and Riverine Habitat, ed. Dorava J.M. et al., Water Sci. Appl., AGU, Washington DC, 4, pp. 85-102, 2001.

[19] Mao L., Andreoli A., Comiti F., Lenzi M.A., Geomorphic effects of large wood jams on a sub-Antartic mountain stream. River Research and Application, 24(3), pp. 249-266, 2008.

[20] Mao L., Comiti F., Lenzi M.A., La resistenza al flusso in un torrente montano ad elevata pendenza con morfologia a step-pool. Rivista di Ingegneria Agraria, 3, pp. 29-38, 2006.

[21] Mao L., Comiti F., Andreoli A., Picco L., Lenzi M.A., Urciulo A., Iturraspe R., Iroumè A., Role and management of in-channel wood in relation to flood events in Southern Andes basins. In Monitoring, Simulation, Prevention and Remediation of Dense and Debris Flows II, eds. De Wrachien D., Brebbia C.A., Lenzi M.A., WIT Press, 60, pp. 207-216, 2008.

[22] Mazzorana, B., Zischg, A., Largiader, A., Hubl J., Hazard index maps for woody material recruitment and transport in alpine catchments. Natural Hazards and Earth System Sciences, 9, pp. 197-209, 2009.

[23] Meleason, M.A., Davies-Colley, R.J., Hall, J.M.J., Characterizing the variability of wood in streams: simulation modelling compared with multiple-reach surveys. Earth Surface Processes and Landforms, 32(8), pp. 1164-1173, 2007. 
[24] Méndez Herrera, J.C., Esquivel, L., Inundaciones, deslizamientos, flujos de lodo y detritos: Sus efectos sociales y geológicos en las microcuencas de los ríos Guabas y Portalón (September, 2005). IX Seminario Nacional de Geotecnia, San José, Costa Rica, 14-18 November 2006.

[25] Montgomery, D.R., Collins, B.D., Buffington, K.M., Abbe T.B. Geomorphic effects of wood in rivers. In The Ecology and Management of Wood in World Rivers, eds. Gregory. S.V., Boyer K.L., Gurnell A.M., American Fisheries Society, Bethesda, MD, pp. 21-47, 2003.

[26] Rigon, E., Il legname in alveo nei torrenti alpini: Analisi quantitativa e modellazione GIS. PhD thesis, University of Padova, Italy, pp 178, 2009.

[27] Sidle, R.C. \& Ochiai, H. Landslides: Processes, Prediction, and Land Use. Water Resources Monograph, AGU, Washington DC, 18, pp. 312, 2006.

[28] Wilcox, A., Nelson, J.M., Wohl E.E., Flow resistance dynamics in steppool channels: 2. Partitioning between grain, spill, and woody debris resistance. Water Resources Research, 206, 42, W05419. DOI: 10.1029/2005WR004278, 2005. 